\title{
Financing in strategic areas for the competitiveness of commercial companies
}

\author{
Financiamiento en áreas estratégicas para la competitividad de las empresas \\ comerciales
}

AGUILAR-PÉREZ, Esmeralda†**, PÉREZ-MEJÍA, Salvador and IRIGOYEN-ARROYO, Luis Ernesto

Instituto Tecnológico Superior de San Martín Texmelucan

ID $1^{\text {st }}$ Author: Esmeralda, Aguilar-Pérez / ORC ID: 0000-0001-6794-9630, Researcher ID Thomson: O-3376-2018, CVU CONACYT ID: 625314

ID $1^{\text {st }}$ Coauthor: Salvador, Pérez-Mejía / ORC ID: 0000-0002-8755-0587, Researcher ID Thomson: O-3429-2018, CVU CONACYT ID: 947145

ID $2^{\text {nd }}$ Coauthor: Luis Ernesto, Irigoyen-Arroyo / ORC ID: 0000-0002-2037-1621, Researcher ID Thomson: O-6659-2018, CVU CONACYT ID: 472901

DOI: $10.35429 / J M M E .2019 .4 .3 .24 .33$

Received February 25, 2019; Accepted June 14, 2019

\begin{abstract}
This is a research (cross-sectional, non-experimental quantitative approach) based on a survey, of a sample for convenience of 365 micro, small and medium-sized commercial enterprises (MSMEs). The objective of the present was to identify the association that exists between the financing and the competitiveness of the MSMEs of the commerce sector, for which the correlations were determined using the Stata software of the 3 analyzed variables (sales, quality and environmental management) with a level of $5 \%$ significance, with the results obtained, the correlation map of the 3 variables was prepared. Therefore, it is stated, what is the degree of correlation that exists between the financing applied to the areas of (sales, quality and environmental management) and the competitiveness of the SMEs of the commerce sector? The study reveals that the MSMEs, show a correlation of $0.9917,0.8971$, and 0.9220 in the variables of sales, quality and environmental management respectively, which means that the MSMEs that used the financing resources in the sales areas, achieved a competitiveness greater than those that used them for the quality area and that financing environmental management contributes to the competitiveness of the company.
\end{abstract}

Financing, Competitiveness, Commercial companies

\begin{abstract}
Resumen
Se trata de una investigación (enfoque cuantitativo de tipo transversal, no experimental) basada en una encuesta, de una muestra por conveniencia de 365 empresas comerciales micro, pequeñas y medianas (MiPyMEs). El objetivo del presente fue identificar la asociación que existe entre el financiamiento y la competitividad de las MiPyMes del sector comercio, para lo cual se determinaron las correlaciones utilizando el software Stata de las 3 variables analizadas (ventas, calidad y gestión ambiental) con un nivel de significancia del 5\%, con los resultados obtenidos se elaboró el mapa de correlaciones de las 3 variables. Por lo que en el presente se plantea ¿Cuál es el grado de correlación que existe entre el financiamiento aplicado a las áreas de (ventas, calidad y gestión ambiental) y la competitividad de las MiPyMes del sector comercio?. El estudio revela que las MiPyMes, muestran una correlación de $0.9917,0.8971$, y 0.9220 en las variables de ventas, calidad y gestión ambiental respectivamente, lo que significa que las MiPyMes que utilizaron los recursos de financiamiento en las áreas de venta, lograron una competitividad mayor que las que los utilizaron para el área de calidad y que financiar la gestión ambiental contribuye a la competitividad de la empresa.
\end{abstract}

Financiamiento, Competitividad, Comerciales

Citation: AGUILAR-PÉREZ, Esmeralda, PÉREZ-MEJÍA, Salvador and IRIGOYEN-ARROYO, Luis Ernesto. Financing in strategic areas for the competitiveness of commercial companies. RINOE Journal- Macroeconomics and monetary economy. 2019. 3-4: 24-33.

\footnotetext{
* Correspondence to Author (email: esmeralda.aguilar@itssmt.edu.mx)

$\dagger$ Researcher contributing first author.
} 


\section{Introduction}

In 2016, the Organization for Economic Cooperation and Development (OECD) said that one of the problems that affect MSMEs in the trade sector in emerging countries is the failure to implement financing projects. The main cause of the disappearance of micro, small and medium enterprises (MSMEs) is directly related to the inappropriate use of the financing they obtain for their activities. This problem affects the MSMEs of all economic sectors, however, in this article the results of the study carried out on 365 commercial SMEs of the Central South region of Mexico are disclosed, which according to data from the National Institute of Statistics and Geography (INEGI) statistics of the last economic census (2016) support that ninety percent of Mexican MSMEs are considered in the commerce sector. The prominence of the company of the commerce sector in the productive fabric is absolutely evident. In statistical terms it is proven that, both in our country and worldwide, these MSMEs play a fundamental role in the creation of wealth and employment.

The Inter-American Development Bank (IDB), through the Multilateral Investment Fund (MIF) defines financing projects as those whose objective is to improve the competitiveness of a defined set of small-scale, sectoral and geographically concentrated companies, through of collective actions.

The problem is that these MSMEs do not use these resources properly, since they are allocated to items that do not generate value, which represents a problem of indebtedness and lack of liquidity to deal with it.

According to the study carried out in 2016 by the Inter-American Development Bank (IDB), the competitiveness of MSMEs must be related to the correct functioning of the variables of (sales, quality and environmental management), therefore, it is essential that the MiPyMes allocate financial resources so that these areas work properly, as expressed by León and Noemí (2019) in their study conducted in a group in Peru, financing improves the profitability of them as long as they are properly allocated.
Due to the above in the investigation, what is the degree of correlation that exists between the financing applied to the areas of (sales, quality and environmental management) and the competitiveness of the MSMEs of the commerce sector ?, for which it is going to Identify the association that exists between the financing and the competitiveness of the MSMEs of the commerce sector, determining the correlations of the variables of sales, quality and environmental management.

This article is made up of six sections, the first corresponds to the background, in the second the theories and concepts that support the work are made known, in the third section the methodology used to obtain the results is described. they present section four and finally they present the conclusions of the work and the references of the same.

\section{Background}

Regarding the implementation of the financing projects, Cárdenas (2013) in Peru determined that the implementation of financing projects increases the sales of goods or services. García and Piña (2013) in Venezuela analyzed the valuation of productive investments with the objective of determining the creation of financial and intellectual value. On the other hand Álvarez (2013) carried out a study of the MSMEs of the commerce sector in Honduras to determine their link with development. Carrión, Zula and Castillo (2016) analyzed the management strategy in MiPyMes and the application of financing projects in the Catering industry (food service) in Ecuador. Martínez in Chile in 2012, analyzed the strategies for the use of micro financing, in order to generate financial education in micro entrepreneurs, which allows the proper use of money. Aguilar, Pinzón and Duran (2015), studied the implications of financing projects in commercial MSMEs of textile products in the rural areas of YucatanMexico. In addition, Kú, et al., (2013) evaluated financing projects in commercial MSMEs with local sustainability criteria in Calakmul, Mexico, to determine how these projects are selfsustaining. On the other hand Ramírez, Pérez and Hernández (2013), analyzed the financing projects for migrants to establish micro of the commerce sector supported by the $3 \times 1$ Program for Migrants in the period 2007-2011 in Zacatecas. 
Another work carried out by Reyes and Pacheco (2014), allowed us to analyze two experiences of micro-commercial financing in the States of Oaxaca and Yucatán comparing, the way in which entrepreneurs face adverse situations such as crisis and lack of liquidity.

\section{Theoretical framework}

Studies are being carried out in different countries for the development of a strategy that will allow those of the commerce sector to continue operating and contribute to their competitiveness, however, among the most important problems of those of the commerce sector, the problems arising from the inappropriate use of resources stand out financial features that the company has, this causes a malfunction of the organization that can be seen in: lack of liquidity that causes little or no growth, in addition to that it is very easy to confuse flows of the trade and professional sector, which is shown in demotivation and lack of growth.

Despite previous studies regarding the SMEs of the commerce sector, it is detected that an area of opportunity for these MSMEs is to design a strategy that implements financing projects as a form of financing or liquidity (Desyllas and Sako, 2013).

In order for the SMEs of the commerce sector of the commerce sector to become more competitive and keep pace with the market, the SMEs of the commerce sector must be supported through adequate financial management (Xi, Kraus, Filser and Kellermanns, 2015).

\section{Methodology}

This is a research (cross-sectional, nonexperimental quantitative approach) based on a survey, of a sample for convenience of 365 micro, small and medium-sized commercial enterprises (MSMEs).

\section{Research subjects}

Starting from the fact that the objective of this research is to identify the association that exists between the financing and the competitiveness of the MSMEs of the commerce sector, determining the correlations of the variables of sales, quality and environmental management, which allow them to improve their competitiveness and favor local development, the profile of the research subjects is as follows: directors, managers, partners and owners of those of the commerce sector of the central south region of Mexico.

In this research, the participants that were studied were the MSMEs of the commercial sector of the central south region of Mexico, according to the Mexican Business Information System (SIEM) there are 123,338 registered that were taken as a base, of which $45 \%$ are commercial , $30 \%$ of services and the rest are industrial as can be seen in table 1 .

\begin{tabular}{|c|c|c|c|c|}
\hline State & $\begin{array}{l}\text { Total } \\
\text { Establishments }\end{array}$ & $\begin{array}{l}\text { Industrial } \\
\text { Sector } \\
25 \%\end{array}$ & $\begin{array}{l}\text { Services } \\
\text { Sector } \\
\mathbf{3 0 \%}\end{array}$ & $\begin{array}{l}\text { Commercial } \\
\text { Sector } 45 \%\end{array}$ \\
\hline Michoacán & 55,228 & 13807 & 36568 & 24853 \\
\hline Puebla & 22,767 & 5692 & 6830 & 10245 \\
\hline Querétaro & 17,881 & 4470 & 5364 & 8046 \\
\hline Tlaxcala & 10,756 & 2689 & 3227 & 4840 \\
\hline Hidalgo & 10,710 & 2678 & 3213 & 4820 \\
\hline Guerrero & 3,978 & 995 & 1193 & 1790 \\
\hline Morelos & 2,018 & 505 & 605 & 908 \\
\hline Total & 123,338 & 30835 & 37001 & 55502 \\
\hline
\end{tabular}

Table 1 Companies registered in the SIEM

Source: own elaboration with data obtained from the electronic portal of (SIEM) March 2018

\section{Conceptual analysis}

To affirm that financing in the strategic areas of (sales and operations, quality and environmental management) improves the competitiveness of MSMEs in the commerce sector of the Central South Region of Mexico. The linear relationship between competitiveness and its dimensions was determined: sales and operations, quality and environmental management for which the conceptual analysis mentioned in the following figure 1 was proposed. 


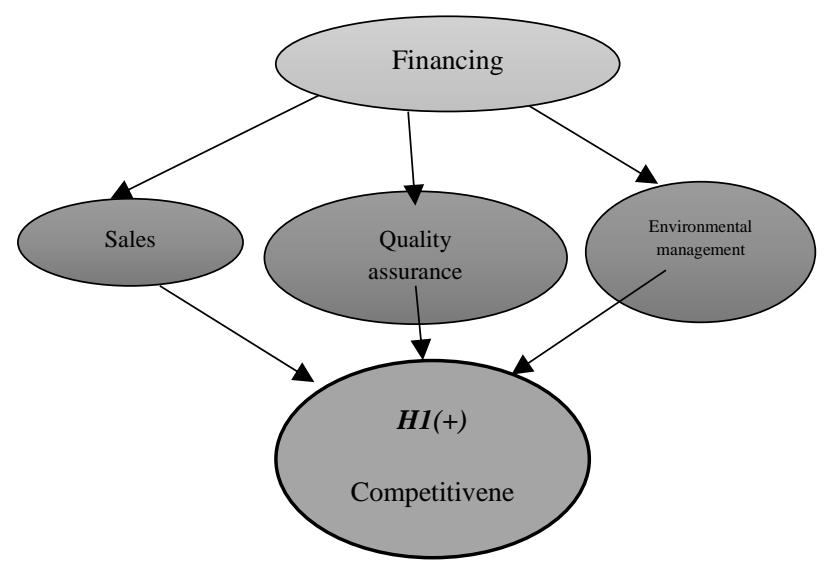

Figure 1 Proposed Conceptual Analysis Source: self made

The basic conceptual analysis that guides the research originated from the literature review and taking the 3 variables of the IDB competitiveness map that are: sales and operations, quality assurance and environmental management, analyzing the indicators of each variable such as shown in table 2 below.

\begin{tabular}{|c|c|}
\hline Variables & Indicators \\
\hline $\begin{array}{l}\text { Sales and } \\
\text { operations }\end{array}$ & $\begin{array}{l}\text { - Sales planning and process, } \\
\text { - Sales capacity, } \\
\text { - Maintenance, } \\
\text { - Investigation } \\
\text { development, } \\
\text { - Provisioning, } \\
\text { - Inventory management. }\end{array}$ \\
\hline Quality assurance & $\begin{array}{l}\text { - General aspects of quality, } \\
\text { - Quality systems }\end{array}$ \\
\hline $\begin{array}{l}\text { Environmental } \\
\text { management }\end{array}$ & $\begin{array}{l}\text { - } \text { Company environmental } \\
\text { policy, } \\
\text { - Strategy to protect the } \\
\text { environment, } \\
\text { - Awareness and training of } \\
\text { personnel in environmental } \\
\text { issues }\end{array}$ \\
\hline
\end{tabular}

Table 2 Indicators of the variables to study

Source: BID, 2016

\subsection{Hypothesis Development}

The literature review developed provides the theoretical elements that allow the identification and construction of relationships between the different questions analyzed. From the different relationships represented in the proposed conceptual analysis, figure 1 , the different research hypotheses were constructed, which are justified and presented below.

Hypothesis 1:
H1. The financing implemented in the area of sales and operations is directly related to the competitiveness of MSMEs in the commerce sector.

\section{Hypothesis 2:}

$\mathrm{H} 2$. The financing implemented in quality assurance is directly related to the competitiveness of MSMEs in the commerce sector.

\section{Hypothesis 3:}

H3 The financing implemented in environmental management is directly related to the competitiveness of the SMEs of the commerce sector.

\section{Results}

\section{Statistical description of Sales and Operations}

Based on the notation described above, the following statistical results were obtained from the 365 surveys received. For Sales and Operations, these results are reflected in table 3 below.

\begin{tabular}{|l|r|r|r|}
\hline \multicolumn{1}{|c|}{ Sum } & \multicolumn{2}{c|}{ \% } & \multicolumn{1}{c|}{ Average } \\
\hline TDA & 207 & $12.5 \%$ & 20.7 \\
\hline DA & 625 & $37.9 \%$ & 162.5 \\
\hline NAND & 288 & $17.5 \%$ & 28.8 \\
\hline ED & 332 & $20.1 \%$ & 133.2 \\
\hline TED & 198 & $12.0 \%$ & 19.8 \\
\hline TOTAL & $\mathbf{1 6 5 0}$ & $\mathbf{1 0 0 . 0 \%}$ & $\mathbf{3 6 5 . 0}$ \\
\hline
\end{tabular}

Table 3 Statistical description of the Sales and Operations Source: self made

Based on table 3, it can be seen that of the 1,650 reagents received for this item, 207 reagents were found to correspond to those who totally agree (ADD), in which the financing in the sales areas is directly related to the competitiveness of the commercial ones, these reagents represent $12.5 \%$ of the total reagents; 625 reagents are also in agreement (DA) in that the financing in the sales areas have a direct relation in the competitiveness of the commercials, these reagents represent $37.90 \%$ of the total, Therefore, both criteria (TDA + DA) add up in total 832 reagents, which represent $50.04 \%$ of the total reagents received. 
On the other hand, it is also observed that 288 reagents received by the MSMEs of the commerce sector, consider that they neither agree nor disagree (NAND) with which the strategic planning in the sales areas have a direct relation in the competitiveness of the commercial MSMEs, these reagents represent only $17.5 \%$ of the total reagents for this item. Finally, 332 reagents of the surveys received responded that they disagree (ED), while 198 reagents coincided with the criterion Totally Disagree (TED). These reagents represent $20.1 \%$ and $12.0 \%$ of the total reagents received respectively, therefore, adding both criteria (ED + TED) give a total of 530 reagents, which represent $32.1 \%$ of the total reagents received by the MSMEs of the sector trade of the central south region of Mexico participants.

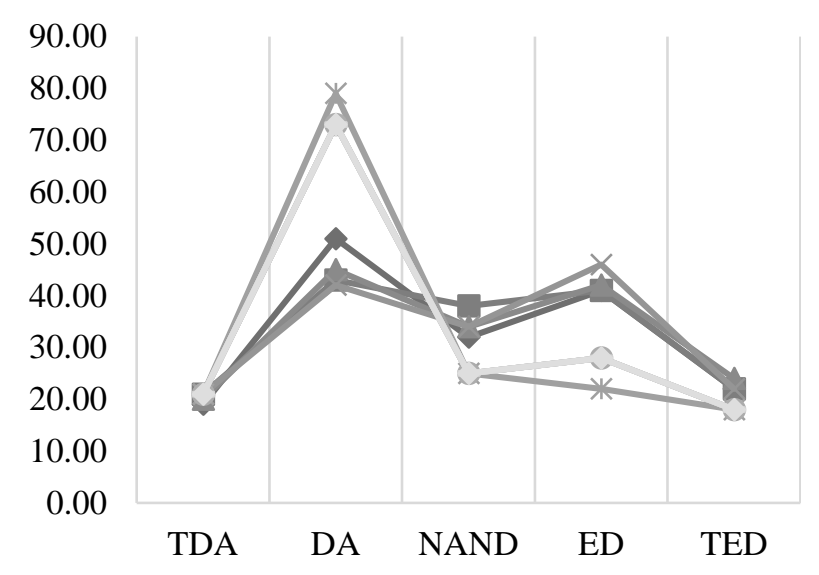

Graphic 1 Statistics of the Sales and Operations heading Source: self made

Graphic 1 denotes the distribution presented by the ten items that make up the sales and operations item. It shows that the majority of respondents agree that financing in the areas of sales and operations are directly related to the competitiveness of commercial MSMEs.

\section{Statistical description of the item Quality Assurance}

Based on table 4, it can be seen that of the 1,320 reagents received for this item, it was found that 161 reagents correspond to those who totally agree (ADD), in which the financing in the areas of Quality Assurance are related Directly in the competitiveness of commercials, these reagents represent $12.2 \%$ of the total reagents; Thus also 390 reagents agree (DA) that financing in sales areas has a direct relationship in the competitiveness of commercials, these reagents represent $29.50 \%$ of the total.
Therefore, both criteria (ADD + DA) add up in total 551 reagents, which represent $41.70 \%$ of the total reagents received.

\begin{tabular}{|l|r|r|r|}
\hline \multicolumn{1}{|c|}{ Sum } & \multicolumn{2}{c|}{ Average } \\
\hline TDA & 161.00 & $12.2 \%$ & 20.1 \\
\hline DA & 390.00 & $29.5 \%$ & 148.8 \\
\hline NAND & 251.00 & $19.0 \%$ & 31.4 \\
\hline ED & 342.00 & $25.9 \%$ & 142.8 \\
\hline TED & 176.00 & $13.3 \%$ & 22.0 \\
\hline TOTAL & $\mathbf{1 3 2 0 . 0 0}$ & $\mathbf{1 0 0 . 0 \%}$ & $\mathbf{3 6 5 . 0}$ \\
\hline
\end{tabular}

Table 4 Statistical description of the item Quality Assurance

Source: self made

On the other hand, it is also observed that 251 reagents received by the MSMEs of the commerce sector, consider that they neither agree nor disagree (NAND) with which the financing in the areas of quality assurance is directly related to The competitiveness of commercial MSMEs, these reagents represent only $17.5 \%$ of the total reagents for this item.

Finally, 342 reagents of the surveys received responded that they disagree (ED), while 176 reagents coincided with the criterion Totally Disagree (TED). These reagents represent $25.9 \%$ and $13.3 \%$ of the total reagents received respectively, therefore, adding both criteria (ED + TED) give a total of 518 reagents, which represent $39.2 \%$ of the total reagents received by the MSMEs of the sector trade of the central south region of Mexico participants.

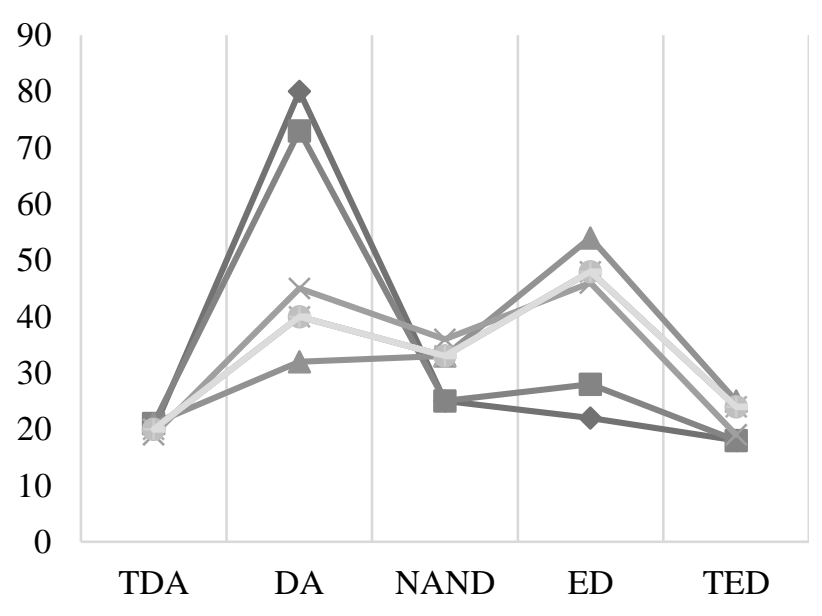

Graphic 2 Statistics of the Quality Assurance item Source: self made

In graphic 2, denotes the distribution presented by the 8 items that make up the Quality Assurance item. It shows that the majority of respondents agree that financing in the areas of quality assurance is directly related to the competitiveness of commercial MSMEs.

AGUILAR-PÉREZ, Esmeralda, PÉREZ-MEJÍA, Salvador and IRIGOYEN-ARROYO, Luis Ernesto. Financing in strategic areas for the competitiveness of commercial companies. RINOE Journal- Macroeconomics and monetary economy. 2019 


\section{Statistical description of the heading Environmental Management Analysis}

Based on table 5, it can be seen that of the 1,155 reagents received for this item, it was found that 140 reagents correspond to those who totally agree (ADD), in which the financing in the areas of Environmental Management Analysis have Direct relationship in the competitiveness of commercials, these reagents represent $12.1 \%$ of the total reagents; Thus also 280 reagents agree (DA) that financing in the areas of environmental management are directly related to the competitiveness of commercials, these reagents represent $24.2 \%$ of the total, Therefore, both criteria (ADD + AD) total 420 reagents, which represent $36.3 \%$ of the total reagents received.

\begin{tabular}{|l|l|l|l|}
\hline & Sum & \multicolumn{2}{l|}{ Average } \\
\hline TDA & 140.00 & $12.1 \%$ & 20.0 \\
\hline DA & 280.00 & $24.2 \%$ & 140.0 \\
\hline NAND & 231.00 & $20.0 \%$ & 33.0 \\
\hline ED & 336.00 & $29.1 \%$ & 148.0 \\
\hline TED & 168.00 & $14.5 \%$ & 24.0 \\
\hline & 1155.00 & $100.0 \%$ & 365.0 \\
\hline
\end{tabular}

Table 5 Statistical description of the heading Environmental Management Analysis

Source: self made

On the other hand, it is also observed that 231 reagents received by the MSMEs of the commerce sector, consider that they neither agree nor disagree (NAND) with which the financing in the areas of environmental management is directly related to the Competitiveness, these reagents represent only $20 \%$ of the total reagents for this item.

Finally, 336 reagents of the surveys received responded that they disagree (ED), while 168 reagents coincided with the criterion Totally Disagree (TED). These reagents represent $29.1 \%$ and $14.5 \%$ of the total reagents received respectively, therefore, adding both criteria (ED + TED) give a total of 504 reagents, which represent $43.6 \%$ of the total reagents received by the MSMEs of the sector trade of the central south region of Mexico participants.

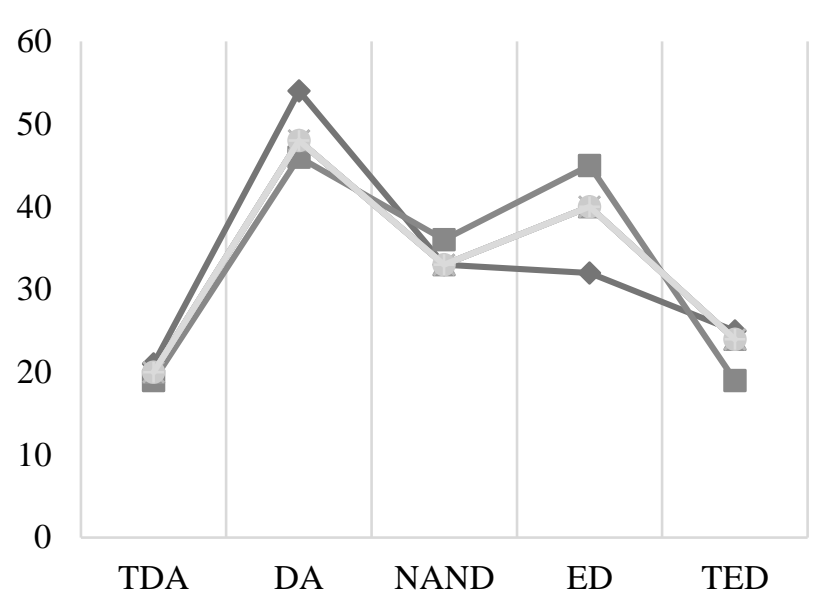

Table 5 Statistical description of the heading Environmental Management Analysis Source: self made

Graphic 3, denotes the distribution presented by the 7 items that make up the Environmental Management Analysis heading. It shows that the majority of respondents agree that financing in the areas of Environmental Management Analysis is directly related to the competitiveness of their companies.

\section{Descriptive statistics of the constructs}

The descriptive statistical results of the variables included in the instrument are presented below.

\section{Sales and Operations}

Ten statements measured this construct, in all the items, the minimum value in all the variables was 1 (totally disagree) and the maximum value in all the variables was 5 (totally agree). The item with the lowest average was "The strategies proposed by your company provide that you have an adequate supply of products and supplies" (2.5758), and the item with the highest average was "Your company for the supply with its suppliers manages a plan of negotiation "(3.1394). The item with the highest standard deviation was "Your company for the supply with its suppliers manages a negotiation plan" (1.2634), while the item with the lowest standard deviation was "The operations performed in your company have organization manuals and procedures" (1.1261). 


\section{Quality assurance}

For this construct, eight sentences were measured. In all items, the minimum value in all variables was 1 (totally disagree) and the maximum value in all variables was 5 (totally agree). The item with the lowest average was "In your company there are records that allow process control" (2.6788) which also represents the lowest standard deviation (1.1261), and the item with the highest average was "In your company the vision and mission is known to all collaborators "(3.1758) which also represents the largest standard deviation (1.2923).

\section{Environmental Management Analysis}

For this construct, seven sentences were measured. In all the items, the minimum value in all the variables was 1 (totally disagree) and the maximum value of all the variables was 5 (totally agree). The item with the lowest average was "The company applies an environmental policy" (2.9152), and the item with the highest average was "The company performs actions that allow it to be considered socially responsible" (3.0909). The item with the highest standard deviation was "The company applies an environmental policy" (1.2803), while the item with the smallest standard deviation was "In your company you are taking actions to raise awareness of environmental issues" (1.2171).

\section{Strengths and Weaknesses of the trade sector in the central south region of Mexico}

The following is an analysis of the strengths and weaknesses of the MSMEs in the commerce sector of the central south region of Mexico based on the survey data. For the aforementioned analysis, the Likert rating scale used in this study is taken into account, considering 1 (Strongly agree) as the most desirable and 5 (Strongly disagree) the least desirable. Although the grade point average is above the average, it is convenient to point out which of them should be maintained and in which of them there is a possibility of improvement. Those variables that were above the average were defined as strength, which, according to the table, was 2.95 . Therefore, a variable with an average value $\geq$ 2.95 will indicate a strength and a variable with an average value $<2.95$ will indicate a weakness. Table 6 shows the average of the variables and the average of all of them.

\begin{tabular}{|l|r|r|r|r|}
\hline \multicolumn{2}{|c|}{$\begin{array}{l}\text { Sales and } \\
\text { operations } \\
\text { analysis }\end{array}$} & $\begin{array}{l}\text { Quality } \\
\text { Assurance } \\
\text { Analysis }\end{array}$ & $\begin{array}{l}\text { Environmental } \\
\text { Management } \\
\text { Analysis }\end{array}$ & \multicolumn{1}{c|}{ Total } \\
\hline Mean & 2.85 & 3.00 & 3.02 & 2.95 \\
\hline $\begin{array}{l}\text { Standard } \\
\text { deviation }\end{array}$ & 1.2303 & 1.2497 & 1.2536 & 1.2454 \\
\hline
\end{tabular}

Table 6 Average and standard deviation of study variables Source: self made

\section{Strengths}

Analysis of Environmental Management: For this variable there is an average of 3.02, which is the best qualified and a standard deviation of 1.2536 , the values of this variable indicate that for the MSMEs of the sector in question the social responsibility of the company before taking care of the environment, it places her in a situation where she can improve her image before society.

Quality Assurance Analysis: The average of this variable was 3.00 and its standard deviation of 1.2497. In this variable we can see that in the commerce sector all the activities that are carried out are in order to offer a product or service free of defects and that at the same time satisfies the needs of the consumer.

\section{Weakness}

Sales and operations analysis: with an average of 2.85 and a standard deviation of 1.2303 , it is considered that the sales and operations strategies are properly applied in the MSMEs of the sector analyzed here, however, having a low value, believes that there is an opportunity for improvement in the administration of operations that create value in the form of goods and services by transforming inputs into finished products.

\section{Analysis of the reliability of the analysis}

The statistical validity of the instrument was estimated by determining the correlations between the dimensions as shown in Table 7 . 


\begin{tabular}{|c|c|c|c|}
\hline & $\begin{array}{l}\text { Sales } \\
\text { Analysi } \\
\text { s }\end{array}$ & $\begin{array}{l}\text { Quality } \\
\text { Assuranc } \\
\text { e Analysis }\end{array}$ & $\begin{array}{l}\text { Environmenta } \\
\text { I Management } \\
\text { Analysis }\end{array}$ \\
\hline $\begin{array}{l}\text { Sales and } \\
\text { operations } \\
\text { analysis }\end{array}$ & 0.894 & & \\
\hline $\begin{array}{l}\text { Quality } \\
\text { Assurance } \\
\text { Analysis }\end{array}$ & 0.863 & 0.885 & \\
\hline $\begin{array}{l}\text { Environmenta } \\
1 \text { Management } \\
\text { Analysis } \\
\end{array}$ & 0.809 & 0.818 & 0.873 \\
\hline
\end{tabular}

Table 7 Correlation between dimensions Source: self made

The results of Table 7 allow us to affirm that the data collection instrument is reliable in all cases. Similarly, it can be affirmed that it is valid because all correlations are significant and in turn are smaller than the Cronbach's Alpha of the corresponding dimension.

\section{Hypothesis check}

There are three hypotheses that were developed in order to respond to the problem initially raised in the development of this project, which fully identified with the general objective and the specific objectives that were mentioned, then the verification of each of the hypotheses raised.

\section{Hypothesis 1:}

H1. The financing implemented in the area of sales and operations is directly related to the competitiveness of MSMEs in the commerce sector.

\section{Hypothesis 2:}

$\mathrm{H} 2$. The financing implemented in quality assurance is directly related to the competitiveness of MSMEs in the commerce sector.

Hypothesis 3:

$\mathrm{H} 3$ The financing implemented in the environmental management direct relation in the competitiveness of the MSMEs of the commerce sector.

To affirm that the financing of the dimensions of sales and operations, quality and environmental management, improves the competitiveness of those of the commerce sector of the Central South Region of Mexico.
The linear relationship between competitiveness and its dimensions was determined: sales and operations, quality and environmental management for which the conceptual analysis that had already been mentioned in Figure 1 was proposed. To reinforce hypotheses 1,2 and 3 mentioned above and to confirm the conceptual analysis presented in Figure 1, correlation tests were performed between the dependent variable and each and every one of the independent variables, grouped in the Sales and Operations blocks., Quality of products and services and Environmental Management. For this, the three correlation matrices corresponding to each of the blocks were calculated. Next, table 8 shows the correlations between the profitability of the MSMEs, which in our study is the approximation of competitiveness, and the variables that have a greater correlation with the profitability of the MSMEs.

\begin{tabular}{|l|l|l|r|}
\hline \multicolumn{2}{|c}{ Indicators } & \multicolumn{2}{c|}{$\begin{array}{l}\text { Correlation } \\
\text { with } \\
\text { Profitability }\end{array}$} \\
\hline Sales Analysis & $\begin{array}{l}\text { Planning and } \\
\text { sales process }\end{array}$ & $\mathrm{pp} 1$ & 0.2350 \\
\cline { 2 - 4 } & Sales capacity & $\mathrm{cp} 1$ & 0.2017 \\
\cline { 2 - 4 } & Maintenance & $\mathrm{mp} 1$ & 0.2072 \\
\hline $\begin{array}{l}\text { Quality } \\
\text { Assurance } \\
\text { Analysis }\end{array}$ & $\begin{array}{l}\text { General aspects } \\
\text { of quality }\end{array}$ & $\mathrm{cop} 3$ & 0.2059 \\
\hline $\begin{array}{l}\text { Environmental } \\
\text { Management } \\
\text { Analysis }\end{array}$ & $\begin{array}{l}\text { Company } \\
\text { Environmental } \\
\text { Policy }\end{array}$ & $\mathrm{pa} 1$ & 0.1796 \\
\hline
\end{tabular}

Table 8 Correlation Chart

Source: self made

As can be seen in Table 8 for the Sales and Operations Analysis indicator, there are three variables that showed a ratio greater than 0.2000 , which is the standard for the case of simple correlations. Being the variables of Planning and sales process (pp1) the one that shows the highest relationship with 0.2350 , followed by the Maintenance variable (mp1) with a ratio of 0.2072 and the third Sales Capacity (cp1) with a ratio of 0.2017 .

In the case of the Quality Assurance Analysis indicator, only one variable showed a higher ratio of 0.2000 , which was the General Aspects of Quality (cop3) variable with a ratio of 0.2059 . 
However, for the Environmental Management Analysis indicator, none of the variables that compose it showed a higher ratio of 0.2000 , which is what was needed to demonstrate that these variables had an impact on the competitiveness of MSMEs in the commerce sector, the variable being Environmental policy of the company (pa1) with a ratio of 0.1796 which showed the highest relationship, however, is not sufficient to be considered valid.

\section{Conclusions}

Based on the above, we can conclude that the financing implemented in the area of sales and operations is directly related to the competitiveness of the MSMEs in the commerce sector. In this case, the variable that has the highest level of correlation is that of the "Sales planning and process" (pp1), which, as can be seen in table 8 , is 0.2350 . It is also concluded that the financing implemented in quality assurance has little direct relation to the competitiveness of the SMEs in the commerce sector. And that hypothesis 3 is not accepted because the financing implemented in environmental management has no direct relationship in the competitiveness of MSMEs in the commerce sector.

Finally, the study reveals that the MiPyMes, show a correlation of $0.9917,0.8971$, and 0.9220 in the variables of sales, quality and environmental management respectively, which means that the MiPyMes that used the financing resources in the sales areas, achieved a greater competitiveness than those that used them for the quality area and that financing environmental management contributes to the competitiveness of the company.

\section{References}

Aguilar, J. L. E., Pinzón, D. G. P. y Duran, A. D. G. (2015). Gestión estratégica y competitiva de las empresas familiares turísticas mexicanas: un estudio empírico. Revista EAN, (66), 5-30.

Álvarez, S. (2013) Las Empresas Familiares en Honduras y su vinculación con el desarrollo. Universidad Católica de Honduras, Dirección de Postgrado e Investigación.
Banco Interamericano de Desarrollo (2016). Guía operativa para programas de la competitividad para la pequeña y mediana empresa. Banco Interamericano de Desarrollo. Washington D.C.

Banco Interamericano de Desarrollo (2016) Orientaciones para la evaluación de proyectos de integración productiva. Banco Interamericano de Desarrollo. Washington D.C.

Cárdenas, F.L.G. (2013) Bancos de tecnología, de proyectos productivos e incubadoras de empresas, en apoyo de las cooperativas y la propiedad social. Revista iberoamericana de autogestión y acción comunal, ISSN 0212-7687, No. 61, 2013, págs. 205-210

Carrión, L., Zula, J., \& Castillo, L. (2016). Análisis del análisis de gestión en pequeñas y medianas empresas y su aplicación en la industria del catering en Ecuador. Ciencia Administrativa, (1), 82-102.

Desyllas, P., y Sako, M. (2013). Profiting from business model innovation: Evidence from PayAs-You-Drive auto insurance. Research Policy, 42(1), 101-116.

García, B., Piña, Z.H. (2013) Institucionalidad venezolana sobre emprendimiento social durante el periodo 1999-2010. Revista Agricultura, sociedad y desarrollo scielo.org.mx

INEGI Censos Económicos (2016). Micro, pequeña, mediana y gran empresa: estratificación de los establecimientos: Censos Económicos 2016 / Instituto Nacional de Estadística y Geografía. México: INEGI

Kú, V.M., Pool, L., Mendoza, J., Aguirre, E. (2013). Propuesta Metodológica para evaluar proyectos productivos con criterios locales de sustentabilidad en Calakmul, México. Avances en Investigación Agropecuaria, vol. 17, núm. 1, pp. 9-34

León, C., \& Noemi, Y. (2019). Caracterización del financiamiento de las micro y MiPyMes del sector comercio del Perú: caso empresa "Ferretería Contreras La Solución SAC" de Chimbote, 2016 
Martínez Jon Echezarraga (2012) Grandes familias empresarias en Chile. Sus características y aportes al país (1830-2012); ESE Business School, Universidad de los Andes Santiago, Chile.

OCDE (2016) Perspectives on Global Development 2016: Boosting productivity to meet the middle-income challenge.

Ramírez, C.R., Pérez, V.O. y Hernández, Z.F. (2013) Los Proyectos Productivos Financiados con Remesas y el 3X1 en los Municipios Zacatecanos y sus Formas de Organización ConCiencia Tecnológica, ISSN-e 1405-5597, $\mathrm{N}^{\mathrm{o}}$. 41, 2011, págs. 13-21

Reyes, C.V. y Pacheco, M.G. (2014) El proyecto productivo la frontera entre lo público y lo privado. Espacios transnacionales: revista latinoamericana-europea de pensamiento y acción social, ISSN-e 2007-9729, Año 2, n. 3, 2014, págs. 145-155

SIEM (2018) Sistema de Información Empresarial Mexicano consultado en marzo2018 de https://siem.gob.mx/consultadeestablecimientos

Xi, J. M., Kraus, S., Filser, M., y Kellermanns, F. W. (2015). Mapping the field of family business research: past trends and future directions. International Entrepreneurship and Management Journal, 11(1), 113-132 